\title{
8 \\ Stereotype Threat and Ten Things We Can Do to Remove the Threat in the Air
}

Franklin A. Tuitt

University of Denver

Lois Reddick

New York University

The purpose of this chapter is to present an overview of the literature related to stereotype threat in an effort to provide faculty members and instructional developers with a better understanding of what the phenomenon is and what can be done about it in college classroom settings. To this end, we reviewed several of the major studies published on the subject between 1995 and 2005 and compiled a list of strategies that reflected both the major empirical findings on stereotype threat and our own research and experiences with faculty and students in college settings. Given the enormity of the subject, we focused heavily on the features of stereotype threat that relate specifically to race but acknowledged that the complexity of the subject required attention to other aspects of identity that may function to lessen, or in some cases increase, the intensity of stereotype threat. The overall findings suggested that there are several ways in which faculty and instructional developers can help to create learning environments that serve to mitigate the impact of stereotype threat, and that more work needs to be done to examine the ways in which faculty and instructional developers can strive to create environments that improve the quality of students' perceptions and academic performances.

$\mathrm{R}$ esearch has shown that for some populations of high-achieving students, taking a difficult exam can produce feelings of anxiety that are rooted in a fear of confirming a negative stereotype about an affiliated group, and that these feelings can result in deficits in performance (Marx \& Roman, 2002; 
Spencer, Steele, \& Quinn, 1999; Steele \& Aronson, 1995). This phenomenon labeled stereotype threat is generally activated when three situational conditions are present: 1) students must be explicitly or implicitly exposed to a negative stereotype about a group with which they can be associated, 2) the testing or learning conditions must pose a challenge to the students, and 3) the testing or learning domain must be of some importance to the students (Steele \& Aronson, 1995). Stereotype threat is strongest among the highest achieving students because academic performance is an integral part of their collective identities. In fact, low-achieving students, who do not perceive the academic domain to be an important indicator of their personal success, are less susceptible to this threat (Major, Spencer, Schmader, Wolfe, \& Crocker, 1998).

Empirical research on stereotype threat demonstrates its impact on the performance of a wide range of student populations, including women (Désert, Gonçalves, \& Leyens, 2005; Quinn \& Spencer, 2001; Shih, Pittinsky, \& Ambady, 1999; Spencer et al., 1999), Latinos (Aronson, Quinn, \& Spencer, 1998; Aronson \& Salinas, 1997; Gonzales, Blanton, \& Williams, 2002), Asians (Shih et al., 1999), gay white males (Bosson, Haymovitz, \& Pinel, 2004), and even white male students who do not traditionally suffer from negative stereotypes in academic domains (Inzlicht \& Ben-Zeev, 2000). In this chapter, we center our discussion on the impact of stereotype threat as it relates to black students in academic settings. Specifically, we provide an overview of the literature related to stereotype threat in an effort to provide faculty members and instructional developers with a better understanding of what this phenomenon is and what can be done about it.

\section{Stereotype Threat: What Is It?}

According to Steele and Aronson (1995), the educational experiences of black students are uniquely affected by the sociopsychological threats that arise when they are engaging in academic activities for which a negative stereotype about their group may apply. This predicament threatens students with the possibility that they may be judged or treated stereotypically and that their academic performance may confirm the stereotype. Taylor and Antony (2000) describe this as the social and psychological sense of peril that negative racial stereotypes may be unfairly applied to black students solely on the basis of their skin color. This threat of being racially stereotyped produces a climate of intimidation that can hamper academic performance (Steele \& Aronson, 1995). Black students may also disidentify with academic goals because of the anxiety that is produced by widely held stereotypes that they are intellectually inferior (Steele, 1997). 


\section{The Impact of Stereotype Threat Related to Race}

Good, Aronson, and Inzlicht (2003) argue that "being evaluated in a stereotyped domain is sufficient to trigger the trademark responses associated with stereotype threat such as a lack of enjoyment of the educational process, increased anxiety and stress, and ultimately, underperformance" (p. 647). These "trademark responses" can contribute to students' underperformance when their academic profiles might suggest otherwise. For example, Steele (1997) argues that when gifted black students sit down to take a difficult exam, "the extra apprehension they feel in comparison with whites is less about their own ability than it is about having to perform on a test and in a situation that may be primed to treat them stereotypically" (p. 52). This conclusion suggests that talented black students who perceive their learning environment to be racialized may not perform up to their ability (Carter \& Tuitt, 2006). This underperformance appears to be rooted less in black students' self-doubt than in their social mistrust of the learning environment (Steele, 1999).

While stereotype threat is commonly known for the detrimental impact it has on standardized test scores, research also indicates that individuals may suffer negative performance outcomes such as less engagement with academics because of the burden black students may experience when confronted with "the prospect of confirming cultural stereotypes impugning their intellectual and academic abilities" (Good et al., 2003, p. 647). According to Osborne (2001), there is empirical support for the assertion that black students do in fact have increased anxiety or arousal that can inhibit participation when performing in academic arenas. He argues that the racial performance gaps may be explained through "the cognitive effects of increasing anxiety, which include decreasing cognitive capacity, reticence to respond, attention deficits, and distracting thoughts" (p. 293). This evidence suggests that for some black students the "threat in the air" existing in predominantly white classrooms may not simply be a figment of their imagination (Tuitt, 2003).

\section{Removing the Threat in the Air}

Although a significant amount has been written about the impact of stereotype threat and what can be done about it, this information is not widely disseminated among those who work within the field of higher education and faculty/teaching assistant development. The identification of pedagogical interventions and learning strategies that potentially reduce the impact of stereotype threat is vitally important if we are to create teaching and learning environments in which all students have a chance to reach their potential. 


\section{Creating Identity-Safe Learning Environments}

According to Davies, Spencer, and Steele (2005), attempting to eliminate all potentially threatening cues from the learning environment would be a futile exercise, but it may be possible to create environments that effectively reduce the risk of experiencing stereotype threat. In addition, Taylor and Antony (2000) suggest that students' academic performance can be improved through instructional strategies that reduce stereotype threat and assure students that they will not be cast in the shadow of negative stereotypes. Essentially, professors have the responsibility of creating identity-safe environments where their students' sense of the institution is not a barrier to their academic success (Davies et al., 2005). According to Davies et al., identity-safe environments challenge the validity, relevance, or acceptance of negative stereotypes linked to stigmatized social identities. These identity-safe environments would remove the threat in the air, allowing stigmatized individuals to enter previously threatening situations without the risk of confirming a negative stereotype targeting their social identity (Markus, Steele, \& Steele, 2002; Steele, 2004).

\section{Ten Strategies for Removing the Threat in the Air}

In the next section, we discuss ten strategies that instructors can employ to create identity-safe environments and combat stereotype threat in the classroom. These recommendations emerge out of the current literature on stereotype threat and provide educators with some pedagogical practices they can undertake to remove the potential threat in the air.

\section{$\because 1$. Create optimistic and personalized teacher-student relationships.}

Steele and Aronson (1995) suggest that the prevailing stereotypes based on prior experiences with racism make it reasonable for talented black students to worry that professors in their institutions will doubt their academic abilities. Steele (1997) proposes that one "wise strategy," suitable for all students, is to discredit this assumption through the establishment of potential-affirming faculty-student relationships. Likewise, Baker (1998) found that students were able to develop effective relationships with the faculty members who demonstrated behaviors such as being supportive, caring, knowledgeable, challenging, concerned, and open to establishing an interpersonal relationship. These attributes focus on the faculty member's ability to relate to the student on an interpersonal level and are essential for a positive learning environment (Baker, 1998). In such personalized and optimistic teacher-student relationships, instructors make their confidence in students explicit (Taylor \& Antony, 2000). 


\section{Affirm students' sense of belonging.}

According to Steele (1997), negative-ability stereotypes raise the threat that one does not belong in the learning environment: "They cast doubt on the extent of one's abilities, on how well one will be accepted, on one's social compatibility with the domain, and so on" (p. 625). The more that instructors can provide direct affirmation of students' belongingness-that is, assuring individuals that they are welcomed, supported, and valued (Davies et al., 2005) in the classroom-the more effective they will be in removing the threat in air. This affirmation has to be genuine and authentic, and Steele warns that it is important to base this affirmation on the students' intellectual potential.

\section{Build students' self-efficacy.}

Nauta, Epperson, and Kahn (1998) found that interventions designed to help students develop more accurate views of their past and present performances led to increases in perceptions of self-efficacy, which contributed to higher level aspirations in career achievement for mathematics, science, and engineering majors. Steele (1997), building on Bandura's $(1986,1997)$ theory of self-efficacy, advises that instructors attempt to develop students' sense of competence and self-efficacy in the schooling domain. He contends that for students who are threatened by a poor reputation and who probably hold internalized doubts about their ability, the Socratic method is one pedagogical intervention that has the potential to create a safe teacher-student relationship where there is little cost of failure and the gradual building of self-efficacy from small gains. In addition, other research indicates that a strong racial identity may serve as a buffer against stereotype threat (McFarland, Lev-Arey, \& Ziegert, 2003). For example, Smith and Hopkins (2004) found that students who possess a strong sense of self-determination and pride about self are able to perform better on more complex tasks than others who do not demonstrate these characteristics.

4. Create authentic opportunities for students to affirm their individuality. Ambady, Paik, Steele, Owen-Smith, and Mitchell (2004) contend that if the salience of group identity is replaced by the salience of individual identity, the risk associated with negative stereotype activation might be attenuated and performance altered to reflect more accurately the unique capabilities of the individual rather than the stereotypes in the group. Moreover, these authors suggest that the disclosure of personal information accentuating one's unique qualities encourages a more multifaceted view that may distinguish a person 
from his or her in-group and counteract stereotyping. In theory, a person might overcome a self-threat by affirming "the broader self-concept or an equally important, yet different, aspect of the self-concept" (Ambady et al., 2004, p. 405). Thus, if professors are able to create opportunities for their students to represent themselves in genuine, authentic, and meaningful ways, it is more likely that students will trust that their academic efforts will be judged by merit and not some stereotypic impression (Carter \& Tuitt, 2006).

\section{Hold students to high standards.}

Taylor and Antony (2000) argue that providing students with "challenging, rather than remedial expectations and academic work, which builds on promise and potential, not failure" (p. 187) can eliminate the potential threat in the air. For example, Cohen, Steele, and Ross (1999) observed that giving challenging work and critical feedback to students demonstrates a respect for their potential and shows "that they are not regarded through the lens of an ability-demeaning stereotype" (Steele, 1997, p. 625). Baker (1998) observed that "faculty members created a positive learning atmosphere by challenging students and demonstrating concern and belief in the (academic) ability of students" (p. 58).

6. Teach students about the nature of intelligence and stereotype threat. According to Taylor and Antony (2000), emphasizing the expandability of intelligence lets students know that skills can be learned and extended through education and experience. Steele (1997) posits that the extent to which schooling can stress what Dweck (1986) called the incremental nature of human intelligence-its expandability in response to experience and training-should help to deflect the meanest implication of the stereotype. Aronson (2004) cites empirical research that indicates the benefits of teaching students to view their intellectual abilities as expandable rather than fixed. He contends that stereotypes impose on students the notion that their academic difficulties reflect an "unalterable limitation, a bell curve view of abilities that says that some people are born smart and others dumb" (p. 17). Essentially, Aronson contends that when we teach students about a human being's ability to expand intelligence, we inform our students to think of their minds as muscles: use it and it is strengthened; waste it and it atrophies. Finally, according to Aronson, studies show the value of explicitly teaching students about stereotype threat. Learning that their test anxiety results from a common response to stereotyping helps students interpret their struggles in a less pejorative and anxiety-producing way and results in higher test scores (Aronson \& Williams, 2004). 
4.7. Value multiple perspectives.

According to Steele (1997), concerns that students may have about whether they are going to be assessed in stereotypical ways can be addressed by being explicit in regard to the value of multiple perspectives. This refers to strategies that explicitly value a variety of approaches to both academic substance and the larger academic culture in which that substance is considered. "Making such a value public tells stereotype-threatened students that this is an environment in which the stereotype is less likely to be used" (Steele, 1997, p. 625). In Baker's (1998) study, students identified the professor's ability to be "unbiased" and open to diverse perspectives as being very important to the establishment of an effective faculty-student relationship. In this context, openness did not just involve an openness to students but an openness to the diverse perspectives of others as well (Baker, 1998). Another way that faculty members can demonstrate that they value multiple perspectives is to make sure that the course content (readings and examples) is diverse. According to Osborne (2001), the utilization of a truly multicultural curriculum can help to undermine the negative group stereotypes related to intellectual ability. Alternatively, Adams (2005) argues that the absence of a diverse curriculum can cause black students to internalize marginalized status as a result of not seeing themselves reflected in the course readings. Thus, when professors include positive examples of diverse individuals they provide counternarratives that help to delegitimize the potentially negative stereotypes floating in the air (Marx \& Goff, 2005).

\section{Create cooperative learning environments.}

Social psychologists and others examining the impact of stereotype threat have advocated for the development of learning environments rooted in fairness, high expectations, trust, and collaboration, not competition. For example, Aronson (2004) argues that creating cooperative classroom structures in which students work interdependently can produce immediate and dramatic gains in grades, test scores, and engagement of students of color because such environments reduce competition, distrust, and stereotyping among students (Aronson \& Patnoe, 1997). Marx, Brown, and Steele (1999) report that creating cooperative learning environments minimizes competition among students, builds trust, and facilitates student success.

\section{:92. Provide role models.}

Aronson (2004) suggests that exposing students to role models who have triumphed over similar academic struggles with hard work and persistence markedly improves the students' study habits, grades, and test scores. 
Specifically, people from the stereotype-threatened group who have been successful in the domain carry the message that stereotype threat is not an insurmountable barrier (Aronson, 2004). "The presence of role models of people who have successfully overcome stereotype threat" demonstrates to students that the potential threat in the air does not have to be a barrier to their success (Taylor \& Antony, 2000, p. 106). The research of Marx and Goff (2005) suggests that something as simple as who administers a test (or stands in front of the class) can change the attitudes black students have about how they might be racially stereotyped. In this regard, the extent to which institutions can diversify their faculty and staff may have a tremendous impact on their ability to remove the threat in the air.

\section{M.0. Address test taking anxiety.}

Several researchers note that explicitly telling students that an exam is racially fair, reporting to students specific aspects of their performance that indicate their capacity to perform at high levels (Spencer et al., 1999; Stone, Lynch, Sjomeling, \& Darley, 1999), and exposing students to stereotype-disconfirming evidence (e.g., a mathematics professor of Latino or African descent) all function to mitigate the effects of stereotype threat. In addition, Steele and Aronson (1995) found that decreasing the diagnosticity of an exam by telling students that a given test is not an indicator of their intellectual ability minimizes the impact of stereotype threat.

\section{Conclusion}

Although it is virtually impossible to eliminate all of the potentially threatening cues (Davies et al., 2005), professors have the responsibility to create identity-safe environments where their students' racialized sense of the institution is not a barrier to their academic success (Davies et al., 2005). In theory, if faculty do the following, they can clear the air of any potential stereotype threat:

- Create optimistic and personalized teacher-student relationships.

- Affirm students' sense of belonging.

- Build students' self-efficacy.

- Create authentic opportunities for students to affirm their individuality.

- Hold students to high standards.

- Teach students about the nature of intelligence and stereotype threat. 
- Value multiple perspectives.

- Create cooperative learning environments.

- Provide role models.

- Address test taking anxiety.

The results of the various studies cited in this chapter have major implications for faculty and for those who do the work of instructional development. It is clear that instructors can create learning environments that produce differential outcomes for students based on their status and sociopsychological location in the classroom. In this regard, it is crucial that educational institutions be capable of developing professors who are cognizant of stereotype threat and the impact it can have on the learning environment. Moreover, institutions need to hold instructors accountable for the role they play in creating identity-threatening learning environments. Assessment and evaluation of instructors at the institutional level is vital. Finally, more attention needs to be paid to how we prepare doctoral candidates for postsecondary teaching. Graduate programs should ensure that there are a variety of opportunities for aspiring professors to hone their teaching skills prior to arriving in their first college classroom as an instructor (Carter \& Tuitt, 2006). Graduate programs responsible for preparing the next generation of college professors must ensure that future instructors have the pedagogical knowledge and skills needed to create classrooms where all students, regardless of their background, have the opportunity to achieve at the highest levels—-free from the threat of being stereotyped.

\section{References}

Adams, T. A. (2005). Establishing intellectual space for black students in predominantly white universities through black studies. Negro Educational Review, 56(4), 285-299.

Ambady, N., Paik, S., Steele, J., Owen-Smith, A., \& Mitchell, J. P. (2004). Deflecting negative self-relevant stereotype activation: The effects of individuation. Journal of Experimental Social Psychology, 40(3), 401-408.

Aronson, E., \& Patnoe, S. (1997). The jigsaw classroom: Building cooperation in the classroom (2nd ed.). New York, NY: Longman.

Aronson, J. (2004, November). The threat of stereotype. Educational Leadership, 62(3), 14-19. 
Aronson, J., Quinn, D. M., \& Spencer, S. J. (1998). Stereotype threat and the academic underperformance of minorities and women. In J. Swim \& C. Stangor (Eds.), Prejudice: The target's perspective (pp. 83-103). San Diego, CA: Academic Press.

Aronson, J., \& Salinas, M. F. (1997). Stereotype threat, attributional ambiguity, and Latino underperformance. Unpublished manuscript.

Aronson, J., \& Williams, J. (2004). Stereotype threat: Forewarned is forearmed. Unpublished manuscript.

Baker, P. (1998). Students' perception of classroom factors that impact success for African-American students in higher education settings (Doctoral dissertation, Northern Illinois University, 1998). Dissertation Abstracts International, 59, 1434.

Bandura, A. (1986). Social foundations of thought and action: A social cognitive theory. Englewood Cliffs, NJ: Prentice Hall.

Bandura, A. (1997). Self-efficacy: The exercise of control. New York, NY: W. H. Freeman.

Bosson, J. K., Haymovitz, E. L., \& Pinel, E. C. (2004). When saying and doing diverge: The effects of stereotype threat on self-reported versus non-verbal anxiety. Journal of Experimental Social Psychology, 40(2), 247-255.

Carter, D., \& Tuitt, F. (2006, October). Black achievers' experiences with and responses to stereotype threat and racial microaggressions. Paper presented at the BOTA Think Tank, Atlanta, GA.

Cohen, G. L., Steele, C. M., \& Ross, L. D. (1999). The mentor's dilemma: Providing critical feedback across the racial divide. Personality and Social Psychology Bulletin, 25(10), 1302-1318.

Davies, P. G., Spencer, S. J., \& Steele, C. M. (2005). Clearing the air: Identity safety moderates the effects of stereotype threat on women's leadership aspirations. Journal of Personality and Social Psychology, 88(2), 276-287.

Désert, M., Gonçalves, G., Leyens, J.-P. (2005). Stereotype threat effects upon behavior: The role of actual control. Manuscript submitted for publication.

Dweck, C. S. (1986, October). Motivational processes affecting learning. American Psychologist, 41(10), 1040-1048.

Gonzales, P. M., Blanton, H., \& Williams, K. J. (2002). The effects of stereotype threat and double-minority status on the test performance of Latino women. Personality and Social Psychology Bulletin, 28(5), 659-670.

Good, C., Aronson, J., \& Inzlicht, M. (2003, December). Improving adolescents' standardized test performance: An intervention to reduce the effects of stereotype threat. Journal of Applied Developmental Psychology, 24(6), 645-662. 
Inzlicht, M., \& Ben-Zeev, T. (2000). A threatening intellectual environment: Why females are susceptible to experiencing problem-solving deficits in the presence of males. Psychological Science, 11(5), 365-371.

Major, B., Spencer, S., Schmader, T., Wolfe, C., \& Crocker, J. (1998). Coping with negative stereotypes about intellectual performance: The role of psychological disengagement. Personality and Social Psychology Bulletin, 24(1), 34-50.

Markus, H. R., Steele, C. M., \& Steele, D. M. (2002). Color blindness as a barrier to inclusion: Assimilation and nonimmigrant minorities. In R. Shweder, M. Minow, \& H. R. Markus (Eds.), Engaging cultural differences: The multicultural challenge in liberal democracies (pp. 453-472). New York, NY: Russell Sage Foundation.

Marx, D. M., Brown, J. L., \& Steele, C. M. (1999, Fall). Allport's legacy and the situational press of stereotypes. Journal of Social Issues, 55(3), 491-502.

Marx, D. M., \& Goff, P. A. (2005, December). Clearing the air: The effect of experimenter race on target's test performance and subjective experience. British Journal of Social Psychology, 44(4), 645-657.

Marx, D. M., \& Roman, J. S. (2002, September). Female role models: Protecting women's math test performance. Personality and Social Psychology Bulletin, 28(9), 1183-1193.

McFarland, L. A., Lev-Arey, D. M., \& Ziegert, J. C. (2003). An examination of stereotype threat in a motivational context. Human Performance, 16(3), 181-205.

Nauta, M. M., Epperson, D. L., \& Kahn, J. H. (1998, October). A multiple-groups analysis of predictors of higher level career aspirations among women in mathematics, science, and engineering majors. Journal of Counseling Psychology, 45(4), 483-496.

Osborne, J. W. (2001, July). Testing stereotype threat: Does anxiety explain race and sex differences in achievement? Contemporary Educational Psychology, 26(3), 291-310.

Quinn, D. M., \& Spencer, S. J. (2001, Spring). The interference of stereotype threat with women's generation of mathematical problem-solving strategies. Journal of Social Issues, 57(1), 55-71.

Shih, M., Pittinsky, T., \& Ambady, N. (1999, January). Stereotype susceptibility: Identity salience and shifts in quantitative performance. Psychological Science, 10(1), 80-83.

Smith, C. E., \& Hopkins, R. (2004, March). Mitigating the impact of stereotypes on academic performance: The effects of cultural identity and attributions for success among African American college students. Western Journal of Black Studies, 28(1), 312-321. 
Spencer, S. J., Steele, C. M., \& Quinn, D. M. (1999). Under suspicion of inability: Stereotype vulnerability and women's math performance. Journal of Experimental Social Psychology, 35, 4-28.

Steele, C. M. (1997). A threat in the air: How stereotypes shape intellectual identity and performance. American Psychologist, 52(6), 613-629.

Steele, C. M. (1999, August). Thin ice: Stereotype threat and black college students. The Atlantic Monthly, 284(2), 44-54.

Steele, C. M. (2004). Kenneth Clark's context and mine: Toward a context-based theory of social identity threat. In G. Philogène (Ed.), Racial identity in context: The legacy of Kenneth B. Clark. Washington, DC: American Psychological Association.

Steele, C. M., \& Aronson, J. (1995, November). Stereotype threat and the intellectual test performance of African Americans. Journal of Personality and Social Psychology, 69(5), 797-811.

Stone, J., Lynch, C. I., Sjomeling, M., \& Darley, J. M. (1999). Stereotype threat effects on Black and White athletic performance. Journal of Personality and Social Psychology, 77(6), 1213-1227.

Taylor, E., \& Antony, J. S. (2000, Summer). Stereotype threat reduction and wise schooling: Towards the successful socialization of African American doctoral students in education. Journal of Negro Education, 69(3), 184-198.

Tuitt, F. (2003). Black souls in an ivory tower: Understanding what it means to teach in a manner that respects and cares for the souls of African American graduate students. Unpublished doctoral dissertation, Harvard University, Cambridge, MA. 